УДК 331.45

DOI https://doi.org/10.31392/NPU-nc.series5.2020.78.01

Абільтарова Е. $\boldsymbol{H}$.

\title{
ЦІЛІ ФОРМУВАННЯ КУЛЬТУРИ БЕЗПЕКИ ПРОФЕСІЙНОЇ ДІЯЛЬНОСТІ У МАЙБУТНІХ ІНЖЕНЕРІВ 3 ОХОРОНИ ПРАЦІ
}

У статті порушується проблема формування культури безпеки професійної діяльності у майбутніх інженерів з охорони пращі. Встановлено, щзо важливим завданням побудови педагогічної системи формування культури безпеки професійної діяльності у майбутніх інженерів з охорони прачі є визначення і обгрунтування цілей навчальної діяльності учнів.

Мета статті - проектування та обтрунтування цілей формування культури безпеки професійної діяльності у майбутніх інженерів з охорони праці.

На основі методу систематизації та узагальнення наукових знань представлено теоретичний аналіз наукових публікацій щзодо побудови дерева иілей $і$ етапів його проектування. Автором запропоновано такі рівні изілей: генеральна ціль (рівень держави), стратегічна цүіль (рівень вищого навчального закладу), тактичні цілі (рівень конкретних навчальних дисииплін). Визначено, щчо генеральна иіль відображає планований результат запропонованої методичної системи формування культури безпеки професійної діяльності у майбутніх інженерів з охорони прачі; стратегічна ціль спрямована на формування у майбутніх інженерів з охорони праці мотиваційно-цуіннісних орієнтирів у безпеці, професійній компетентності в галузі охорони праиі.

На основі узагальнення практичного досвіду описано тактичні иілі, серед яких виділено такі: нормативна, ідентифікаційна, методична, організаційно-технічна, комунікативна, моніторингова. Зроблено висновок, щзо виділені стратегічні і тактичні изілі сприяють реалізації компетентнісного підходу та професійній підготовиі інженерів з охорони праиі, спрямованій на поглиблення і вдосконалення працеохоронних знань, вмінь і навичок, необхідних для здійснення безпечної професійної діяльності.

Ключові слова: культура безпеки, професійна діяльність, професійна підготовка, інженер з охорони праці, цілі навчання, методика охорони праці.

Важливим завданням побудови педагогічної системи формування КБПД у майбутніх інженерів 3 охорони праці є визначення і обгрунтування цілей навчальної діяльності учнів. Цілепокладання як філософська категорія є основою будь-якої людської діяльності, воно розглядається як процес постановки деяким суб'єктом цілей і завдань для себе або для інших суб' єктів. У загальному випадку цей процес багато разів повторюється. Результатом процесу цілепокладання є мета - планований підсумок подальшої діяльності суб'єкта. Діяльність, яка позбавлена мети, непродуктивна [4, с. 3].

Питанням педагогічного цілепокладання свої роботи присвятило чимало вітчизняних і зарубіжних вчених (С. Батишев, В. Беспалько, Б. Блум, О. Коваленко, І. Лернер, О. Новіков, Н. Нічкало, В. Радкевіч, А. Хуторський). Аналіз літературних джерел показує, що мета визначається як ідеальне, уявне передбачення результату діяльності, де як безпосередній мотив мета спрямовує і регулює людську діяльність [2].

Результати аналізу наукової літератури демонструють різні підходи вчених до методів побудови цілей, одним із яких є «дерево цілей», що є упорядкованою ієрархією цілей, яка характеризує їх підпорядкованість і внутрішні взаємозв'язки. Дерево цілей має ієрархічну структуру, отриману шляхом поділу основної мети на підцілі [7, с. 210].

Н. Вересов виділив сім етапів у постановці цілей: прояснення подробиць (аналіз ситуації і виявлення результатів досягнення мети); з'ясування можливостей (виявлення умов і засобів досягнення цілей); прийняття рішень про те, що потрібно; вибір одного або кількох можливих напрямів; уточнення мети; встановлення часових меж; контроль досягнень [1].

О. Коваленко в методиці професійного навчання виділила три рівні цілеутворення: глобальний, етапний, оперативний. На глобальному (стратегічному) рівні цілеутворення, заснованому на стандартах освіти, здійснюється педагогічна інтерпретація суспільно-державного замовлення і побудова моделі особистості учня. На етапному рівні глобальна мета диференціюється в тактичні цілі, які включають цілі гуманітарних, соціально-економічних, фундаментальних дисциплін, цілі професійної підготовки, цілі професійно-орієнтованої підготовки. Рівень оперативного цілеутворення передбачає вивчення окремих тем і розділів дисциплін, які конкретизуються в цілях окремих уроків [3, с. 144].

Для нашого дослідження особливого значення набуває таксономія Б. Блума, який запропонував класифікацію (таксономію) мисленнєвої поведінки від простого відтворення фактів до процесу аналізу і оцінки. Розроблена ним класифікація цілей має ієрархічну шестирівневу структуру, яка включає такі категорії навчальних цілей у когнітивній області: рівень знання, рівень розуміння, рівень застосування, рівень аналізу, рівень синтезу, рівень оцінки [5, с. 7].

В аспекті нашого дослідження привертає увагу монографічна робота В. Радкевич, яка у процесі побудови системи професійного навчання в закладах професійно-технічної освіти художнього профілю виділила такі рівні цілей [8, с. 336]: 
1) загальна ціль, яка полягає у забезпеченні культурно-освітнього ідеалу, заявленого суспільством, художнім виробником на основі оволодіння цінностями духовної культури, національного мистецтва, досвідом художньої діяльності, а також розвитку професійно важливих якостей, необхідних для особистісної і професійної реалізації та самореалізації майбутніх фахівців;

2) підцілі, які забезпечують розвиток компетентнісного, освітнього, виховного та розвивального компонентів, тісно пов'язаних між собою;

3) комплекс стратегічних цілей (компетентнісна, функціональна, технологічна, діяльнісна, комунікативна, освітня цілі);

4) проміжна ціль професійної підготовки фахівців художніх промислів і ремесел, спрямована на навчання сучасним художнім технологіям;

5) оперативні цілі, які реалізовуються на кожному теоретичному і практичному занятті, в позаурочний час.

Нам імпонує підхід цілеутворення М. Михнюк, яка для розвитку професійної культури викладачів спеціальних дисциплін професійно-технічних навчальних закладів будівельного профілю виділила стратегічні цілі (довгострокові), тактичні цілі (проміжні) і оперативні цілі (результат на поточний період). Стратегічні цілі окреслені загальними цілями освіти та задаються ззовні, вони відображають об'єктивні потреби суспільства, визначають як вихідні, так і кінцеві результати практико-педагогічної діяльності викладачів спеціальних дисциплін, забезпечують вирішення комплексу компетентнісних, технологічних та особистісно-розвивальних задач.

Тактичні цілі - це конкретизація стратегічних задач у реальному професійно-педагогічному процесі ПТНЗ, які відповідають тому чи іншому етапу стратегічної задачі й спрямовуються на вдосконалення ціннісної нормативної, дидактичної, методичної, фахової та інших культур, що є складниками професійної культури. Оперативні цілі реалізуються у процесі повсякденної професійно-педагогічної діяльності викладачів спеціальних дисциплін будівельного профілю, в тому числі при підготовці до уроків, виховних заходів [6, с. 209-214].

Розглянуті вище теоретичні положення щодо проблеми цілепокладання в педагогічній науці заклали фундамент нашого дослідження, в якому були визначені такі рівні побудови цілей формування культури безпеки професійної діяльності у майбутніх інженерів з охорони праці: генеральна мета (рівень держави), стратегічна мета (рівень вищого навчального закладу), тактичні цілі (рівень конкретних навчальних дисциплін).

Генеральна цүіль відображає планований результат запропонованої методичної системи формування культури безпеки професійної діяльності у майбутніх інженерів з охорони праці. Вона викликана потребами суспільства в забезпеченні безпечних і нешкідливих умов праці, в збереженні життя і здоров’я працівників у процесі трудової діяльності. Генеральна мета збігається з потребами суспільства і вимогами ринку праці щодо підготовки інженерів з охорони праці з високим рівнем культури безпеки.

Стратегічна цุiль спрямована на формування у майбутніх інженерів з охорони праці мотиваційно-ціннісних орієнтирів у безпеці, професійної компетентності в галузі охорони праці, розвиток у них професійноважливих і особистісних якостей, необхідних для виконання різних завдань професійної діяльності. Стратегічна мета реалізується в таких підцілях: мотиваційно-ціннісній, компетентнісній, розвиваючій.

Мотиваційно-изіннісна стратегічна ц̧іль формування культури безпеки професійної діяльності у майбутніх інженерів з охорони праці передбачає наповнення освітнього процесу професійної підготовки інженерів 3 охорони праці мотиваційними цінностями і потребами в області безпеки. У процесі реалізації цієї мети майбутні інженери з охорони праці повинні чітко усвідомлювати важливість вивчення міжнародних стандартів управління в галузі охорони праці, необхідність оволодіння видами діяльності щодо забезпечення захисту від професійних ризиків, попередження виробничого травматизму, виявлення порушень законодавства про охорону праці та вимог безпеки.

Компетентнісна стратегічна ціль базується на компетентнісному підході, який передбачає формування у майбутніх інженерів з охорони праці професійної компетентності в галузі охорони праці, що $є$ комплексом професійних знань, умінь, навичок, компетенцій, досвіду професійної діяльності. Реалізація цієї мети на етапі підготовки бакалаврів здійснюється через зміст комплексу дисциплін, які включають працеохоронний, організаційно-управлінський, правовий, ергономічний, здоров'язберігаючий, комунікативний компоненти. На етапі підготовки магістрантів вказана вище мета розкривається шляхом структурування спеціального курсу «Культура безпеки професійної діяльності» за допомогою лекційних, лабораторних, практичних занять, самостійної діяльності студентів.

Розвиваюча стратегічна ичіль спрямована на розвиток у майбутніх інженерів з охорони праці професійноособистісних якостей і здібностей, необхідних для набуття навичок, що характеризуються високим рівнем культури безпеки професійної діяльності. Майбутній інженер з охорони праці повинен виконувати обов'язки професійної діяльності з урахуванням підвищених вимог безпеки і розвитку усвідомленої культури безпеки у персоналу, бути відповідальним, дисциплінованим, самоорганізованим, виконавчим, обов'язковим, принциповим у прийнятті рішень, вимогливим до персоналу в питаннях дотримання і виконання норм безпеки.

У процесі наукового пошуку і дисертаційних досліджень ми обрали нормативну, ідентифікаційну, методичну, організаційно-технічну, комунікативну, моніторингову цілі. Розглянемо більш детально їх сутнісні характеристики. 
Нормативна изіль спрямована на оволодіння майбутніми інженерами з охорони праці системою знань щодо нормативно-правового забезпечення в галузі охорони праці, трудового законодавства, гігієни праці та виробничої санітарії, електробезпеки та пожежної безпеки. Нормативна мета закладає вміння щодо застосування законодавчих і нормативно-правових актів з охорони праці під час розробки захисних заходів від небезпечних і шкідливих виробничих факторів, що призводять до виробничих травм, а також вміння $з$ аналізу та оцінки ефективності заходів, спрямованих на поліпшення умов праці.

Ідентифікаційна изіль передбачає формування у майбутніх інженерів з охорони праці знань і вмінь 3 ідентифікації шкідливих і небезпечних факторів виробничого середовища та трудового процесу. Під час здійснення цього виду діяльності студенти повинні вміти визначати, передбачати і оцінювати небезпеки й ризики для здоров'я працівників; оцінювати стан виробничого травматизму на основі аналізу статистичних показників; виявляти порушення законодавства про охорону праці та нормативних вимог на об'єкті виробництва; визначати причини і обставини нещасних випадків, професійних захворювань і аварій, встановлювати види подій і кваліфікацію нещасного випадку; оцінювати ефективність заходів щодо попередження виробничого травматизму, збереження здоров’я працівників, удосконалення охорони праці.

Методична ціль виражена в здатності інженера з охорони праці здійснювати діловодство, оперативнометодичне керівництво роботою з охорони праці. Необхідно зазначити, що методична робота інженера 3 охорони праці пов'язана 3 підготовкою проектів наказів 3 питань охорони праці, розробкою локальних актів підприємства, оформленням і належним зберіганням документації з питань охорони праці, складанням звітності з охорони праці за встановленими формами, підготовкою і організацією семінарів, конкурсів 3 питань охорони праці, забезпеченням підрозділів підприємства нормативно-правовими актами 3 охорони праці та інформуванням працівників і керівників структурних підрозділів підприємства про зміни законодавства про охорону праці.

Організаційно-технічна ціль вимагає від майбутніх інженерів з охорони праці знань і вмінь 3 організації системи управління охороною праці на підприємстві та технічної експлуатації обладнання, інструментів, пристосувань, будівель, споруд. До основних завдань реалізації цієї мети ми віднесли такі: організація та забезпечення функціонування системи управління охороною праці на підприємстві; організація атестації робочих місць за умовами праці; утримання будівель, споруд виробничого обладнання, інструментів, пристосувань у належному стані; забезпечення їх безпечного обслуговування, своєчасного проведення обстежень їх технічного стану, проведення планово-попереджувального ремонтів; забезпечення працівників засобами індивідуального захисту та організація їх зберігання, прання, хімчистки, знежирення, а також ремонт і заміна; організація належного безпечного стану території підприємства, внутрішніх доріг і пішохідних переходів, а також належної експлуатації транспортних засобів, спеціальної техніки, засобів зв’язку та передачі інформації; раціоналізація робочих місць відповідно до нормативно-правових актів 3 охорони праці, створення санітарно-гігієнічних і санітарно-побутових умов для працівників.

Моніторингова иіль. Враховуючи, що одним із видів трудової діяльності інженера з охорони праці $\epsilon$ здійснення контролю за дотриманням вимог охорони праці і станом умов праці, то до типових завдань цього виду діяльності ми віднесли контроль за виконанням запланованих заходів з профілактики виробничого травматизму та поліпшення умов праці; систематичну перевірку виробничих систем, приміщень, обладнання на відповідність вимогам безпеки праці; контроль за станом виробничого середовища, правильною ідентифікацією факторів виробничого середовища і трудового процесу, станом здоров'я працівників.

Комунікативна изіль. У процесі вирішення завдань професійної діяльності інженер з охорони праці здійснює взаємодію з різними підрозділами організації, комітетом з охорони праці або уповноваженими особами 3 охорони праці, органами громадського контролю 3 охорони праці, органами державного нагляду і контролю за дотриманням вимог з питань охорони праці, Фондом соціального страхування від нещасного випадку на виробництві та професійних захворювань, органами виконавчої влади, а також сприяє співпраці працівників у сфері охорони праці, передачі та обміну інформацією в галузі охорони праці.

Під досягненням комунікативної цілі формування культури безпеки професійної діяльності у майбутніх інженерів з охорони праці ми розуміємо їх готовність до культурного і професійного спілкування, яка передбачає наявність вмінь здійснювати комунікації в різних іiї видах; уважно слухати свого співрозмовника; працювати в команді; аргументовано висловлювати свої думки; вмінь ведення переговорів; грамотного використання технологій ділової взаємодії в управлінській практиці; вирішення конфліктних ситуацій.

Висновки. Необхідно зробити висновок, що встановлені нами цілі спрямовані на систематичне формування культури безпеки професійної діяльності у майбутніх інженерів з охорони праці. Крім того, виділені стратегічні і тактичні цілі сприяють реалізації компетентнісного підходу та професійній підготовці інженерів з охорони праці, спрямованим на поглиблення і вдосконалення працеохоронних знань, вмінь і навичок, необхідних для здійснення безпечної професійної діяльності. Певні цілі створюють умови для розвитку самосвідомості особистості студента і підвищення рівня його відповідальності за своє здоров’я та життя у процесі праці. 


\section{Використана література:}

1. Вересов Н. Н. Психология управления : учебное пособие. М. : ИД РАО НПО МОДЭК МПСИ, 2006. 304 с.

2. Гершунский Б. С. Прогностические методы в педагогике. Киев : Вища школа, 1974. 208 с.

3. Коваленко О. Е. Методика професійного навчання : підручник. Х. : Вид-во НУА, 2005. 360 с.

4. Крыжановская Н. В. Формирование познавательно-профессиональной активности студентов педагогического вуза с применением метода построения целей. Конщепт. 2015. 02 (февраль). URL: http://e-kon-cept.ru/2015/15052.htm (дата обращения: 16.12.2020).

5. Мурзагалиева А. Е., Утегенова Б. М. Сборник заданий и упражнений. Учебные цели согласно таксономии Блума. Астана : АОО «Назарбаев. Интеллектуальные школы». Центр педагогического мастерства, 2015. 54 с.

6. Михнюк М. І. Розвиток професійної культури викладачів спеціальних дисциплін будівельного профілю : монографія. Кіровоград : Імекс-ЛТД, 2015. 368 с.

7. Сибилева В. Я., Антонов А. П., Дружинина И. А. Подход к построению дерева целей определенной области исследования. Международный научный журнал «Инноващионная наука». № 3. 2016. С. 209-214.

8. Радкевич В. О. Теоретичні і методичні засади професійного навчання у закладах профтехосвіти художнього профілю : монографія / за. ред. Н. Г. Ничкало. К. : УкрШНТЕI, 2010. 424 с.

\section{References:}

1. Veresov N. N. (2006) Psihologiya upravleniya : uchebnoe posobie [Management Psychology : a textbook]. M. : ID RAO NPO MODEK MPSI. 304 s. [in Russian]

2. Gershunskij B. S. (1974) Prognosticheskie metody v pedagogike [Predictive methods in pedagogy]. Kiev : Visha shkola. 208 s. [in Russian]

3. Kovalenko O. E. (2005) Metodyka profesiinoho navchannia : pidruchnyk [Methods of professional training : textbook]. Kh. : Vyd-vo NUA. 360 s. [in Ukrainian]

4. Kryzhanovskaya N. V. (2015) Formirovanie poznavatelno-professionalnoj aktivnosti studentov pedagogicheskogo vuza s primeneniem metoda postroeniya celej [formation of cognitive and professional activity of students of a pedagogical university using the method of constructing goals]. Koncept. 02 (fevral). URL: http://e-kon-cept.ru/2015/15052.htm (data obrasheniya: 16.12.2020) [in Russian]

5. Murzagalieva A. E., Utegenova B. M. (2015) Sbornik zadanij i uprazhnenij. Uchebnye celi soglasno taksonomii Bluma [collection of tasks and exercises. Learning goals according to bloom's taxonomy]. Astana : AOO «Nazarbaev Intellektualnye shkoly». Centr pedagogicheskogo masterstva. 54 s. [in Russian]

6. Mykhniuk M. I. (2015) Rozvytok profesiinoi kultury vykladachiv spetsialnykh dystsyplin budivelnoho profiliu : monohrafiia [Development of professional culture of teachers of special disciplines of construction profile : monograph]. Kirovohrad : ImeksLTD. 368 s. [in Ukrainian]

7. Sibileva V. Ya., Antonov A. P., Druzhinina I. A. (2016) Podhod k postroeniyu dereva celej opredelennoj oblasti issledovaniya [Approach to building a tree of goals for a particular research area]. Mezhdunarodnyj nauchnyj zhurnal «Innovacionnaya nauka». № 3. S. 209-214.

8. Radkevych V. O. (2010) Teoretychni i metodychni zasady profesiinoho navchannia u zakladakh proftekhosvity khudozhnoho profiliu : monohrafiia / za. red. N. H. Nychkalo. [Theoretical and methodological foundations of professional training in institutions of Vocational Technical Education of an artistic profile : monograph]. K. : UkrShNTEI. 424 s. [in Ukrainian]

Abiltarova E. N. Goals of forming professional safety culture of future occupational safety and health engineers

This article touches upon the problem of formation of the culture of safety of professional activity among future occupational safety and health engineers. It has been established that an important task of building the pedagogical system forming the culture of professional activity safety among future occupational safety and health engineers is to determine and substantiate the goals of educational activities of students. The purpose of the article is to design and substantiate the goals of forming the culture of safety of professional activity among future engineers on occupational safety and health.

On the basis of the method of systematization and generalization of scientific knowledge, theoretical analysis of scientific publications regarding the construction of a tree of goals and the stages of its construction is presented.

The author suggests the following levels of goals: general goal (state level), strategic goal (higher educational institution level), and tactical goals (level of specific academic disciplines). It has been determined that the general goal reflects the planned result of the proposed methodological system of formation of the safety culture of professional activity of future occupational safety and health engineers; the strategic goal is aimed at the formation of motivational and value orientations in safety, professional competence in the field of labor protection among future occupational safety and health engineers.

Based on the generalization of practical experience, tactical goals are described and characterized, among which the following are highlighted and defined: normative, identification, methodological, organizational and technical, communicative, monitoring. It is concluded that the identified strategic and tactical goals contribute to the implementation of a competencybased approach and professional training of occupational safety and health engineers aimed at deepening and improving labor protection knowledge, skills and abilities necessary for the implementation of safe professional activities.

Key words: safety culture, professional activity, professional training, occupational safety and health engineer, training objectives, occupational safety and health methodology. 